\title{
COMMENT
}

\section{Is otolith microstructure affected by latitude?}

\author{
H. Huuskonen*
}

Karelian Institute, Department of Ecology, University of Joensuu, PO Box 111, FIN-80101 Joensuu, Finland

This comment arises from the discrepancy between the results of studies on Finnish coregonid otoliths (Lake Pyhäselkä, 62 ${ }^{\circ} \mathrm{N}$ ) and those of Central European fish (Lake Constance, $47^{\circ} \mathrm{N}$ ). In Finnish fish, increment formation was irregular due to prominent subdaily increments which often made the identification of daily increments impossible (Huuskonen \& Karjalainen 1993, 1995), while in Central Europe daily increments were easily differentiated and otolith analysis was utilized in an early life history study (Eckmann \& Pusch 1989). Similarly, in North America, Rice et al. (1987) were able to interpret otolith increment patterns of coregonid larvae collected from Lake Michigan $\left(42^{\circ} \mathrm{N}\right)$. Factors behind this inconsistency have subsequently been investigated in detail, and populationspecific differences (Huuskonen et al. 1998) as well as effect of different growth rates and different calcium concentrations of the water (Eckmann 1998) have been excluded as possible causes.

Another example comes from the marine environment. Suthers \& Sundby (1996) studied growth of juvenile cod Gadus morhua from the north-east Atlantic off northern Norway $\left(65-72^{\circ} \mathrm{N}\right)$ and north-west Atlantic off south-western Nova Scotia, Canada $\left(42.5-44^{\circ} \mathrm{N}\right)$, by back-calculating size-at-age from otolith daily growth increments. Their 2 main conclusions were that (1) growth rate increases due to longer time of daylight in the north, and (2) growth rate is more variable in the north due to a less defined light and dark period during a day (S. Sundby pers. comm.). From their Fig. 2 (Suthers \& Sundby 1996, page 830), it can be seen that the increment structure is much more complex in the northern stock. Personal communication with one of the authors verified this observation to be correct. Further, about $50 \%$ of the otoliths of the Arcto-Norwegian cod were unreadable while only about $10 \%$ of the otoliths of the Nova Scotian cod had to be discarded due to difficulties in interpretation (S. Sundby pers. comm.).

•E-mail: hannu.huuskonen@joensuu.fi
These 2 examples from totally different environments suggest that the appearance of otoliths may be affected by latitude. The most obvious explanation for this possible latitudinal effect is differences in photoperiod. In the freshwater example, the southern population of whitefish experienced 12 to $14 \mathrm{~h}$ light $\mathrm{d}^{-1}$ while in the northern population light intensity at night was under 100 lux for a period of only about $2 \mathrm{~h}$ and complete darkness was never observed (Eckmann \& Pusch 1989, Huuskonen \& Karjalainen 1995). The situation was very similar in the marine case (Suthers \& Sundby 1996). However, several laboratory studies have shown that the role of the photoperiod is not decisive in controlling the periodicity of increment formation since daily increments have been observed to form under normal lightdark cycles as well as constant light or dark conditions (Campana \& Neilson 1985). In the case of coregonids, it has been demonstrated that constant illumination per se does not disrupt the formation of well-defined daily increments (Eckmann 1999, Huuskonen unpubl.). However, if constant light was associated with constant food supply, otolith microstructure became confused so that age determination was no longer possible (Eckmann 1999). Hence, in these laboratory experiments it was possible to obtain fish with otolith increment patterns similar to those of wild Finnish coregonids, and this is the most convincing piece of evidence supporting the concept of latitudinal specificity in otolith microstructure.

Multiple feeding has been reported to cause an increase in the number of subdaily increments (Neilson \& Geen 1982, Campana 1983). The way in which this takes place is not well known, but recently Huuskonen \& Karjalainen (1998) observed that otolith growth is possibly induced after food intake due to an increase in metabolic rate (SDA). If this is the case, peaks in SDA that are associated with distinct meals may result in formation of subdaily increments. At northern latitudes, additional daylight enables the feeding of fish to continue almost throughout the night and, consequently, subdaily increments may mask the regular pattern of daily increments. Differences in fish species, fish size, feeding periodicity, meal quality, meal size and water 
temperature will then determine how otolith micro structure reacts in response. For example, owing to their high metabolic rate, coregonids and other salmonids are among the fishes in which age determination problems most probably may occur.

\section{LITERATURE CITED}

Campana SE (1983) Feeding periodicity and the production of daily growth increments in the otoliths of steelhead trout (Salmo gairdnen) and starry flounder (Platichthys stellatus). Can J Zool 61:1591-1597

Campana SE, Neilson JD (1985) Microstructure of fish otoliths. Can J Fish Aquat Sci 42:1014-1032

Eckmann R (1998) Does water calcium content influence the distinctness of daily growth increments in the otoliths of larval whitefish (Coregonus lavaretus L.)? J Appl Ichthyol 14 (in press)

Eckmann R (1999) The influence of photoperiod and feeding frequency on the distinctness of daily growth increments in larval whitefish (Coregonus iavaretus L.). Limnologica (in press)

Eckmann R, Pusch, $M(1989)$ The influence of temperature on growth of young coregonids (Coregonus lavaretus L.) in a large prealpine lake. Rapp P-v Réun Cons Int Explor Mer 191:201-208
Huuskonen H, Karjalainen J (1993) Growth and daily increments in otoliths of experimentally reared vendace, Coregonus albula (L.), larvae. Aqua Fenn 23:101-109

Huuskonen H, Karjalainen J (1995) Age determination of vendace (Coregonus albula (L.)) and whitefish (C. lavaretus L.) larvae from otoliths. Arch Hydrobiol Spec Issue Adv Limnol 46:113-121

Huuskonen H, Karjalainen J (1998) A preliminary study on the relationships between otolith increment width, metabolic rate and growth in juvenile whitefish (Coregonus lavaretus L.\}. Arch Hydrobiol 142:371-383

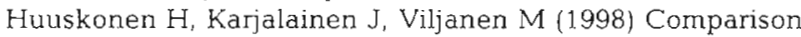
of otolith microstructure in coregonids: are there population-specific differences? Arch Hydrobiol Spec Issue Adv Limnol 50:33-38

Neilson JD, Geen GH (1982) Otoliths of chinook salmon (Oncorhynchus tshawytscha): daily growth increments and factors influencing their production. Can J Fish Aquat Sci 39: $1340-1347$

Rice JA, Crowder LB, Holey ME (1987) Exploration of mechanisms regulating larval survival in Lake Michigan bloater: a recruitment analysis based on characteristics of individual larvae. Trans Am Fish Soc 116:703-718

Suthers IM, Sundby $\$$ (1996) Role of the midnight sun: comparative growth of pelagic juvenile cod (Gadus morhua) from the Arcto-Norwegian and a Nova Scotian stock. ICES J Mar Sci 53:827-836

\title{
Erratum
}

\section{Determining positions for control locations in environmental studies of estuarine marinas}

\author{
T. M. Glasby, A. J. Underwood
}

Mar Ecol Prog Ser 171:1-14, 1998

The analyses of variance as published in Tables 1 \& 4 are wrong. The factor 'Position' should be fixed and orthogonal to the factor 'Creek'. The factor 'Site' should be nested in the interaction between 'Creek' and 'Position'. These changes, however, make no practical difference to the results. The main differences between the 2 analyses are that (1) most tests in the incorrect analysis are less powerful (fewer degrees of freedom) than for the correct design and (2) there is always a test for 'Position' in the correct design. All data have been re-analysed using the correct design and the results are identical to those published, except for Table $4 \mathrm{~b}$, Summer 2 where differences between sites at 3 locations (Cowan Creek, Position 1; Smiths Creek, Position 1; Smiths Creek, Position 2) should have been detected. This makes no difference to any of the conclusions in the paper. Below is a worked example of the correct design for the percentage cover of Cladophorales on plates collected after $5 \mathrm{wk}$ (Summer 1) as presented in Table 1a

\begin{tabular}{|c|c|c|c|c|}
\hline Source & $\mathrm{df}$ & $\begin{array}{c}\text { Summer } 1 \\
\text { MS }\end{array}$ & $F$ & $\mathrm{p}$ \\
\hline \multicolumn{5}{|c|}{ (a) Cladophorales } \\
\hline Creek & 2 & 9707.17 & 46.14 & $\cdots$ \\
\hline Position & 2 & 818.01 & 0.91 & NS \\
\hline Site $(C \times P)$ & 9 & 210.37 & 2.68 & • \\
\hline$C \times P$ & 4 & 898.47 & 4.27 & • \\
\hline Residual & 54 & 78.40 & & \\
\hline
\end{tabular}

